\title{
Do the BGC-I and BGC-II domains of the Aravalli Craton, Northwestern India Represent Accreted Terranes?
}

\author{
Iftikhar Ahmad and M.E.A. Mondal* \\ Department of Geology, Aligarh Muslim University, Aligarh, 202002, India \\ *Email: erfan.mondal@gmail.com
}

\begin{abstract}
Basement complex of the Aravalli craton (NW India) is commonly known as the Banded Gneissic Complex (BGC). It is classified into BGC-I and BGC-II based on the basement-supracrustal relationship and metamorphic grade of their lithologies. The duality of the basement complex, BGC, has been a subject of debate amongst the workers. Many workers postulate that both the domains of the BGC irrespective of its division are Archean. However, recently, workers have shown that the basement complex occurring to the north of Nathdwara (Rajasthan), i.e. the BGC-II is Proterzoic, whereas the BGC-I occurring to the south and east of Nathdwara is largely Archean.

Present work attempts to reconcile various geological attributes of both the BGC-I and the BGC-II and their corresponding lithologies to compare, assess and ascertain whether or not the two domains of the BGC are same. In this endeavour, it is observed that the domains do not bear similar geological history of genesis and evolution. To account for the geological heterogeneity and geochronological age for the corresponding lithologies of both the BGC-I and the BGC-II, it is surmised that the two domains formed and evolved independently which were later accreted and amalgamated to form a single domain.
\end{abstract}

Keywords: BGC, Aravalli craton, terrane accretion, Indian shield, Mangalwar Complex, Sandmata Complex

\section{Introduction}

The Indian shield is largely divided into two domains viz. the North Indian Block (NIB) and the South Indian Block (SIB) separated by the Central Indian Tectonic Zone (CITZ). The Aravalli craton lies on the northwestern edge of the Indian shield which along with the Bundelkhand craton comprises the NIB. Compared to other cratons of the Indian shield, the Aravalli craton remains one of the least studied and least understood craton with regards to its genesis and evolution. Moreover, by and large, the studies conducted on the lithologies of the craton have mostly concentrated on their structural, tectonic and metamorphic aspects, whereas the geochemical as well as the geochronological studies of the lithologies are meagre. Many previous studies on various lithologies of this craton have been made to understand its geological history but due to lack of geochemical and 
geochronological data the task still remains largely unaccomplished. Despite advancements in the analytical techniques pertaining to geochronology and geochemistry, and the fact that geochronology as a tool has tremendously helped the development of the geological science by constraining the ages of the rocks with greater precision, the lithologies of the Aravalli craton remain almost untouched leading to serious knowledge gap of the craton.

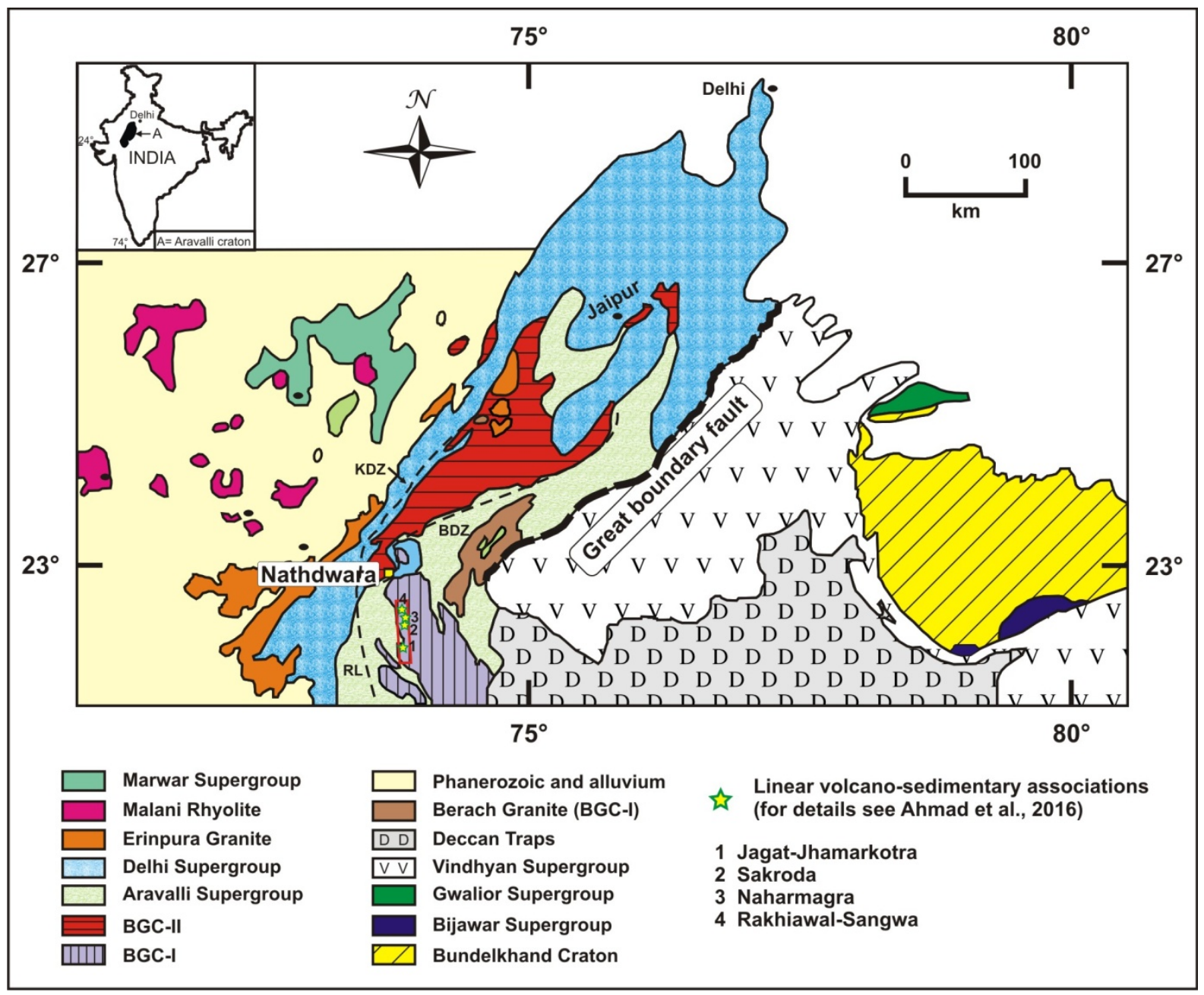

Fig. 1: Regional geological map of the Aravalli craton (after Heron, 1953; Naqvi and Rogers, 1987; Ahmad and Tarney, 1994; Ramakrishnan and Vaidyanadhan, 2008; Meert et al., 2010; Ahmad et al., 2016) showing spatial distribution of the BGC-I and BGC-II along with major dislocation zones/lineaments and younger successions/volcanics. RL: Rakhabdeo Lineament; BDZ: Banas Dislocation Zone; KDZ: Kaliguman Dislocation Zone.

The basement of the Aravalli craton known as the Banded Gneissic Complex (BGC; Gupta, 1934; Heron, 1953) is mainly comprised of basement gneisses, migmatites, amphibolites, undeformed granitoids and metasedimentary rocks of varied ages. The status of the basement complex, BGC, is controversial and has been a topic of debate among workers (cf. Gupta, 1934; Heron, 1953; Naha and Halyburton, 1974; Naha and Roy, 1983). After observing the differences in the grades of metamorphism and basement-supracrustal relationship, Gupta (1934) divided the BGC into: BGC-I (occurring to the east and south of Nathdwara town, Rajasthan); and BGC-II (occurring to the north of Nathdwara town). Presently available database for geochronological ages of various lithocomponents from both 
Open access e-Journal

Earth Science India, eISSN: $0974-8350$

Vol. 9 (IV), October, 2016, pp. 167 - 175

http://www.earthscienceindia.info/

the basement domains also indicate that the two domains are not same. The BGC-I is delineated by the Great Boundary Fault (GBF) on the east, and Banas Dislocation Zone (BDZ) and Rakhabdeo Lineament on the west. On the other hand, the BGC-II is bounded by the Banas Dislocation Zone (BDZ) in the east and the Kaliguman Dislocation Zone in the west. Further, the BGC-II is sub-divided into two domains viz. Mangalwar Complex and Sandmata Complex (Gupta et al., 1980). The present division of the basement complexes into two domains viz. BGC-I and BGC-II, and its related controversies forms the core of the present paper.

The BGC-I (Gupta, 1934), renamed as Mewar Gneiss Complex by Roy (1988), is represented by basement gneisses, undeformed calc-alkaline to potassic granitoids, amphibolites, metasedimentary and ultramafic rocks. The lithologies of the BGC-I do not show any signatures of having been affected by the younger Proterozoic thermal event, which is supposed to have largely changed/reworked the basement rocks of the BGC-II (Gupta, 1934; Roy and Jakhar, 2002). Various workers (see Roy and Jakhar, 2002) suggest that the BGC-II domain of the Aravalli craton has been largely reworked during the Proterozoic tectono-thermal event. It is worth noticing here that despite the occurrence of similar lithologies in both the domains i.e. the BGC-I and the BGC-II of the Aravalli craton, the ages of emplacement of igneous protoliths (Gopalan et al., 1990; Wiedenbeck and Goswami, 1994; Roy and Kroner, 1996; Wiedenbeck et al., 1996; Buick et al., 2006; Dharma Rao et al., 2011), disposition of rock sequences and the pattern of deformation of these lithologies do not bear much similarity (Roy and Jakhar, 2002).

\section{Temporal Evolution}

The basement gneisses of the BGC-I yield emplacement ages between 3.3 to $2.7 \mathrm{Ga}$ (Gopalan et al., 1990; Wiedenbeck and Goswami, 1994; Roy and Kroner, 1996), whereas the basement gneisses of the BGC-II yield much younger ages of $\sim 1.7$ Ga (Fareeduddin and Kroner, 1998; Buick et al., 2006; Dharma Rao et al., 2011). The emplacement age of igneous protolith of the amphibolites occurring within the BGC-I yield $2.83 \mathrm{Ga}$ age (Gopalan et al., 1990), whereas the amphibolites of the BGC-II still remain undated. Despite several differences in the outcrop pattern, which are easily discernible in the field, and the fact that Gupta, 1934 had distinguished the two domains of the basement complex as separate domains, yet the consideration of the BGC-I and the BGC-II as a single basement unit "BGC" still prevails (see Mohanty and Guha, 1995). Mohanty and Guha (1995) in their work considered the amphibolites from both the domains as same. They have quoted the age obtained for the amphibolites of the BGC-I (by Gopalan et al., 1990) for indicating the Archean ancestry of the amphibolites occurring within the BGC-II. The volcano-sedimentary sequence of the BGC-II containing amphibolite layers has been inferred to be a dismembered Archean greenstone belt by Mohanty and Guha (1995). The undeformed granitoids from the BGC-I whose emplacement is considered to mark the stabilisation of the Aravalli craton have yielded ages ranging between 2.6 to $2.4 \mathrm{Ga}$ (Roy and Kroner, 1996; Wiedenbeck et al., 1996). In contrast, the granitoids occurring in the BGC-II have been reported to yield ca. 1.7 Ga ages (Sarkar et al., 1989; Fareeduddin and Kroner, 1998; Biju-Sekhar et al., 2003; Buick et al., 2006; Dharma Rao et al., 2011). This indicates that the BGC-II stabilized at 1.7 Ga, unlike the BGC-I which stabilized at $2.5 \mathrm{Ga}$. If the BGC-I and the BGC-II were a single basement domain representing the basement of the Aravalli craton, then the Proterozoic tectonothermal events affecting the lithologies of the BGC-II should have also affected the 
lithologies occurring within the BGC-I. However, no such evidence for Proterozoic tectonothermal reworking of the lithologies of the BGC-I has been observed or reported by any worker yet (Roy and Jakhar, 2002). Moreover, in contrast to the Archean ancestry of the BGC-I, the emplacement ages for the protoliths of the BGC-II lithologies as reported by several workers are largely Proterozoic (Sarkar et al., 1989; Fareeduddin and Kroner, 1998; Buick et al., 2006; Dharma Rao et al., 2011). Thus, it is quite convincing that the two domains of the Aravalli craton undoubtedly differ with respect to their temporal evolution. The emplacement ages of the igneous protolith and inferred ages of the metasedimentary rocks from both the BGC-I and the BGC-II is summarised in Table-1.

Table-1: Comparison of geochronological ages for the corresponding lithologies of the BGCI and BGC-II domains of the Aravalli craton.

\begin{tabular}{|l|c|c|}
\hline \multirow{2}{*}{ Lithology } & \multicolumn{2}{|c|}{ Age (Ga) } \\
\cline { 2 - 3 } Gneiss & BGC-I & BGC-II \\
\hline Metasediments & $3.3-2.7^{\mathrm{a}, \mathrm{b}, \mathrm{c}}$ & $1.7^{\mathrm{d}, \mathrm{e}, \mathrm{f}}$ \\
\hline Amphibolite & $\begin{array}{c}\text { Archean }^{\mathrm{g}} \\
\text { (older than the amphibolites) }\end{array}$ & $\begin{array}{c}\text { Equivalent to the } \\
\text { amphibolites }\end{array}$ \\
\hline Granitoid (undeformed) & $2.83^{\mathrm{c}}$ & not dated \\
\hline
\end{tabular}

(a) Wiedenbeck and Goswami (1994); (b) Roy and Kroner (1996); (c) Gopalan et al. (1990); (d) Buick et al. (2006); (e) Fareduddin and Kroner (1998); (f) Dharma Rao et al. (2011); (g) Roy et al. (2001); (h) Wiedenbeck et al. (1996); (i) Biju-Sekhar et al. (2003); (j) Sarkar et al. (1989)

\section{Grade of Metamorphism}

The lithologies occurring within the BGC-I domain of the Aravalli craton have been reported to have experienced metamorphism from greenschist up to amphibolite facies, whereas the BGC-II lithologies have undergone metamorphism up to granulite facies. The BGC-II as mentioned earlier has been broadly divided into the Mangalwar Complex and the Sandmata Complex owing to the differences in the highest grades of metamorphism of their lithologies (Gupta et al., 1980; Guha and Bhattacharya, 1995). The lithologies occurring within the Mangalwar Complex of the BGC-II have undergone metamorphism up to amphibolites facies, whereas the Sandmata Complex lithologies show metamorphism up to granulite facies (Gupta et al., 1980, 1997). However, none of the lithology from the BGC-I bearing signatures of granulite facies metamorphism has been reported in the literature (see review by Roy and Jakhar, 2002). This reflects a significant difference in the grade of metamorphism of the lithologies as well as indicates that the two domains are somehow different.

\section{Volcano-Sedimentary Sequence}

In addition to the differences in the ages of emplacement of the igneous protoliths and the grades of metamorphism of the lithologies, the volcano-sedimentary sequences from both the BGC-I and the BGC-II show great variation in their mode of disposition/occurrence and ages (inferred based on the field relationship). The volcano-sedimentary sequences occurring within the BGC-I are not coherent. Our field observations reveal that the metasedimentary lithounits are meagre in the BGC-I as compared to other lithologies and occur in dispersed 
Open access e-Journal

Earth Science India, eISSN: $0974-8350$

Vol. 9 (IV), October, 2016, pp. 167 - 175

http://www.earthscienceindia.info/

small patches which are largely concentrated on the western margin of the domain (Ahmad et al., 2016; Fig. 1). We have also observed that the metasedimentary lithounits of the BGC-I are intruded by amphibolites of $2.83 \mathrm{Ga}$ age (Gopalan et al., 1990). The field evidence for the intrusive nature of amphibolites is seen at several locations such as Sangwa-Rakhiawal, Naharmagra, Sakroda and Jagat (Fig. 2). The metasedimentary lithounit of the BGC-I occurs in the form of rafts, enclaves and caught-up fragments within the amphibolites (Ahmad et al., 2016; Fig. 2).
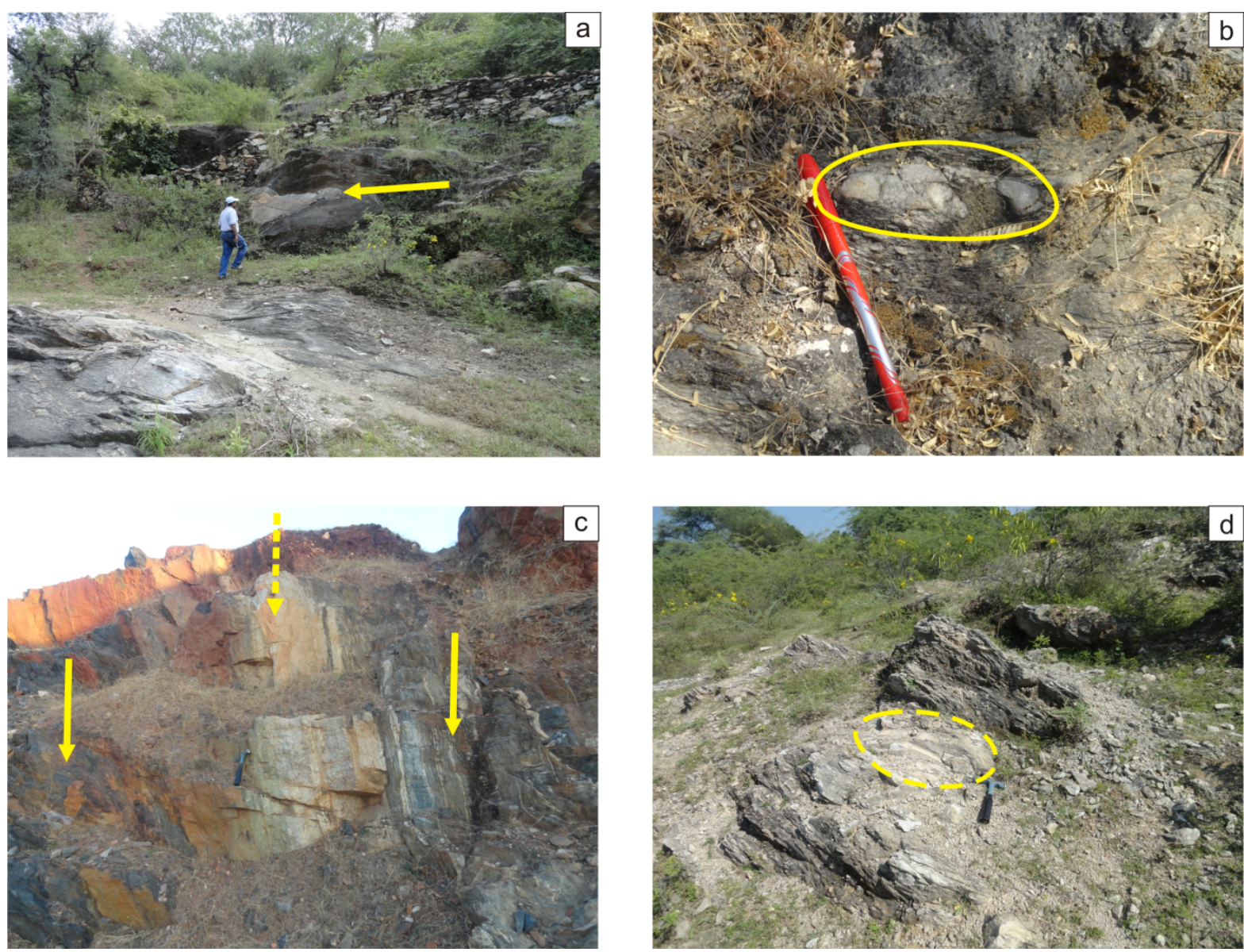

Fig. 2: (a) Raft of quartzite (metasediment) occurring within amphibolites near Jagat (b) Metasedimentary xenolith within intrusive amphibolite at Naharmagra (c) Intrusion of amphibolite [arrow] in metasedimentary lithounit [broken arrow] at Rakhiawal (d) Caught-up fragment of metasediment in amphibolite at Sakroda [Scale: Hammer head $=12.5 \mathrm{~cm} ;$ Pen $=12 \mathrm{~cm}]$

No evidence for penecontemporaneous nature of volcano-sedimentary sequence from the BGC-I has been observed in the field. Roy et al. (2001) obtained detrital zircon ages of $3.23 \mathrm{Ga}$ from the metasedimentary lithounit (quartzites) of the BGC-I which suggests Archean age for its provenance. Furthermore, the intrusion of amphibolites of $2.83 \mathrm{Ga}$ age into the metasedimentary lithounits of the BGC-I indicates that the latter is older as well as Archean $(>2.83 \mathrm{Ga})$ in age. This further suggests that in the BGC-I, sedimentation took place prior to the emplacement of the amphibolite. In the BGC-II, the metasedimentary lithounits occur intercalated with the amphibolites (Fig. 3) indicating that these lithologies are 
contemporaneous/synchronous. Contrary to the BGC-I whereby sedimentation was prior to the emplacement of amphibolites, the intercalations of metasedimentary lithounits and amphibolites in the BGC-II indicate that the sedimentation and magmatism were either synchronous or alternate with both the lithologies being penecontemporaneous. Also, contrary to the occurrence of metasedimentary lithounits in the BGC-I as caught-up fragment, rafts and enclaves, the volcano-sedimentary association in the BGC-II largely occurs as dipping intercalated successions (Fig. 3). In contrast to the inferred Archean ages of the metasedimentary lithounit occurring within the BGC-I, Buick et al. (2006), and Fareduddin and Kroner (1998) reported that the metasedimentary lithounits of the BGC-II were deposited in the Proterozoic rather than in the Archean, as evidenced from the detrital zircon geochronology which has yielded ages between 2293-1698 Ma. From the differences observed in the inferred ages, disposition and mode of occurrence of the volcano-sedimentary successions, it is suggested that the metasedimentary and amphibolites of both the domains are not the same. We opine if these landmark differences in the volcano-sedimentary sequences of both the domains are ignored, it can lead to serious misinterpretations and hence erroneous results.
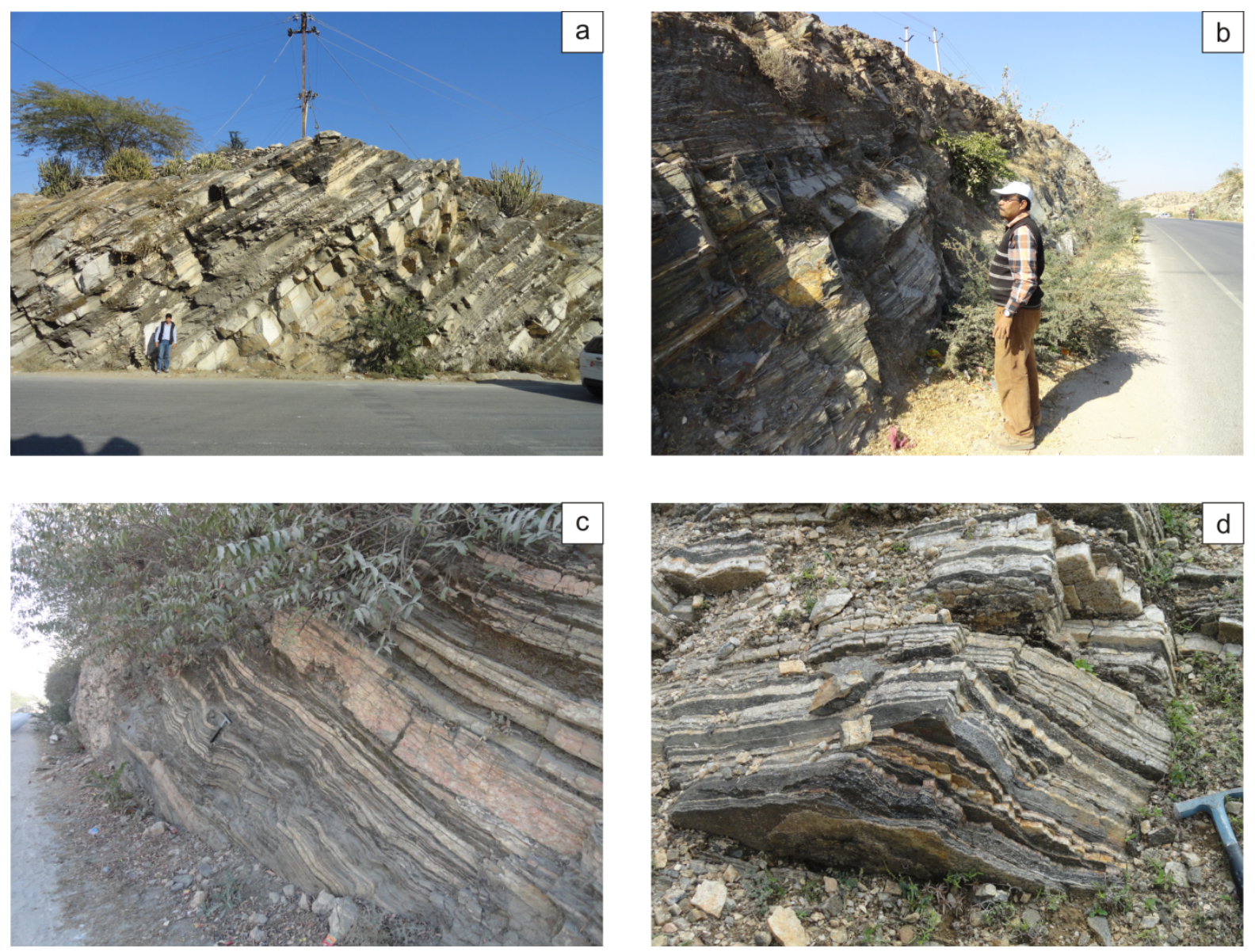

Fig. 3: Easily discernible intercalations shown by the amphibolites and metasedimentary lithounits of BGC-2 indicating contemporaneous ages of both the lithounits. Field photographs of the volcano-sedimentary outcrops from (a) Kelwa near Rajnagar (b) Rajnagar (c) Parasali (d) Merda-Khalsa near Jawariya village [Scale: Hammer head $=12.5 \mathrm{~cm}$ ] 
Open access e-Journal

Earth Science India, eISSN: $0974-8350$

Vol. 9 (IV), October, 2016, pp. 167 - 175

http://www.earthscienceindia.info/

\section{Terrane Accretion: A Proposition}

Despite the differences observed between the two domains of the Aravalli craton (Gupta, 1934; Heron, 1953) very little attention has been paid to decipher their geological history. Geochemical data for most lithounits of the BGC-I are available (e.g. Upadhyaya et al., 1992; Ahmad and Tarney, 1994; Roy and Kroner, 1996; Mondal and Raza, 2013; Rahaman and Mondal, 2015; Ahmad et al., 2016). However, geochemical data for the lithounits of the BGC-II are still lacking. Additionally, BGC-II amphibolites have not been dated so far due to which its age remains unknown. Unavailability of geochemical, isotopic and geochronological data for corresponding lithologies of the domains has been deterrent in drawing a clear picture of their formation and temporal evolution. Also, the lack of well constrained dataset for various lithounits is a reason why the Aravalli craton still remains unrepresented in any computed model for crustal evolution and supercontinent assembly and break up.

Based on the relationship between the volcano-sedimentary rocks, we surmised that the two domains (i.e. the BGC-I and the BGC-II) do not bear similar geological history. In the light of dissimilarities observed in the lithological dispositions, grades of metamorphism and ages of various basement components, the singularity of both the domains of the Aravalli craton can be contested. However, in order to resolve the enigmatic evolutionary history a comprehensive dataset (structural, geochemical, isotopic and geochronological) is still needed. The dataset may hold clue to assess and compare the evolutionary processes, and help us in understanding the evolution of the Aravalli craton as a whole.

From our point of view, we surmise that the two domains of the Aravalli craton are distinctly different and may represent accreted terranes ("terrane" is a geological area possessing distinct lithological assemblages and is bounded by faults). Terrane accretion is a common phenomenon observed in the Precambrian cratons (see Friend et al., 1988; Kusky, 1998; Holtta et al., 2008). The terrane accretion can account for the temporal variations of both the BGC-I and the BGC-II. However, the exact timing of accretion of the terranes (BGC-I and BGC-II) cannot be ascertained as of now, due to lack of comprehensive data for the corresponding lithologies. These accreted terranes share several common features which otherwise have been deceptive in attempts to unravel the geological history of the craton. If terrane accretion comes out to be the plausible reason for the geochronological heterogeneity between the BGC-I and the BGC-II, this study will definitely help the workers to re-assess various previous studies conducted on the Aravalli craton considering them to be a singular domain. Such a study will also be helpful in postulating a model of genesis and evolution for the Aravalli craton. It can also help in determining the status of the two geochronologically distinct basement complexes in various supercontinent configurations. It is further proposed that in order to remove confusion and ambiguity in literatures, the terms BGC-I and BGC-II be adopted as suggested by Gupta (1934) and Sharma (2010).

Acknowledgment: Authors are thankful to the Chairperson, Dept. of Geology, AMU, Aligarh for providing necessary facilities to take up this work. IA is thankful to the University Grants Commission (UGC), New Delhi for the award of Senior Research Fellowship (SRF). The anonymous reviewer is thanked for his valuable suggestions that helped to improve the manuscript. 


\section{References}

Ahmad, I., Mondal, M. E. A. and Satyanarayanan, M. (2016) Geochemistry of Archean metasedimentary rocks of the Aravalli craton, NW India: Implications for provenance, paleoweathering and supercontinent reconstruction. J. Asian Earth Sciences, v. 126, pp. 58-73. doi: 10.1016/j.jseaes.2016.05.019.

Ahmad, T. and Tarney, J. (1994) Geochemistry and petrogenesis of late Archaean Aravalli volcanics, basement enclaves and granitoids, Rajasthan. Precambrian Research, v. 65(1-4), pp. 1-23. doi: 10.1016/03019268(94)90097-3.

Biju-Sekhar, S., Yokoyama, K., Pandit, M. K., Okudaira, T., Yoshida, M. and Santosh, M. (2003) Late Paleoproterozoic magmatism in Delhi Fold Belt, NW India and its implication: evidence from EPMA chemical ages of zircons. J. Asian Earth Sciences, v. 22(2), pp. 189-207. doi: 10.1016/S13679120(02)00188-8.

Buick, I. S., Allen, C., Pandit, M. K., Rubatto, D. and Hermann, J. (2006) The Proterozoic magmatic and metamorphic history of the Banded Gneiss Complex, central Rajasthan, India: LA-ICP-MS U-Pb zircon constraints. Precambrian Research, v. 151(1-2), pp. 119-142. doi: 10.1016/j.precamres.2006.08.006.

Dharma Rao, C. V., Santosh, M., Purohit, R., Wang, J., Jiang, X. and Kusky, T. (2011) LA-ICP-MS U-Pb zircon age constraints on the Paleoproterozoic and Neoarchean history of the Sandmata Complex in Rajasthan within the NW Indian Plate. J. Asian Earth Sciences, v. 42(3), pp. 286-305. doi: 10.1016/j.jseaes.2011.01.018.

Fareeduddin and Kroner, A. (1998) Single zircon age constraints on the evolution of the Rajasthan granulites. In: B. S. Paliwal (ed.) The Indian Precambrian. Jodhpur, India, Scientific Publishers, pp. 547-556.

Friend, C. R. L., Nutman, A. P. and McGregor, V. R. (1988) Late Archaean terrane accretion in the Godthab region, southern West Greenland. Nature, v. 335(6190), pp. 535-538. doi: 10.1038/335535a0.

Gopalan, K., Macdougall, J. D., Roy, A. B. and Murali, A. V. (1990) Sm-Nd evidence for 3.3 Ga old rocks in Rajasthan, northwestern India. Precambrian Research, v. 48(3), pp. 287-297. doi: 10.1016/03019268(90)90013-G.

Guha, D. B. and Bhattacharya, A. K. (1995) Metamorphic evolution and high-grade reworking of the Sandmata Complex granulites. Memoir Geological Society of India, v. 31, pp. 163-198.

Gupta, B. C. (1934) The geology of central Mewar. Memoir Geological Survey of India, v. 65, pp. 107-168.

Gupta, S. N., Arora, Y. K., Mathur, R. K., Iqbaluddin, Prasad, B., Sahai, T. N. and Sharma, S. B. (1980) Lithostratigraphic map of Aravalli region. Geological Survey of India (Hyderabad).

Gupta, S. N., Arora, Y. K., Mathur, R. K., Iqbaluddin, Prasad, B., Sahai, T. N. and Sharma, S. B. (1997) The Precambrian geology of the Aravalli region, southern Rajasthan and northeastern Gujarat. Memoir Geological Survey of India, v. 123, 262 p.

Heron, A. M. (1953) The geology of central Rajputana. Memoir Geological Survey of India, v. 79, 389p.

Holtta, P., Balagansky, V., Garde, A. A., Mertanen, S., Peltonen, P., Slabunov, A., Sorjonen-Ward, P. and Whitehouse, M. (2008) Archean of Greenland and Fennoscandia. Episodes, v. 31(1), pp. 13-19.

Kusky, T. M. (1998) Tectonic setting and terrane accretion of the Archean Zimbabwe craton. Geology, v. 26(2), pp. 163. doi: 10.1130/0091-7613(1998)026<0163:TSATAO>2.3.CO;2.

Meert, J. G., Pandit, M. K., Pradhan, V. R., Banks, J., Sirianni, R., Stroud, M., Newstead, B. and Gifford, J. (2010) Precambrian crustal evolution of Peninsular India: A 3.0 billion year odyssey. J. Asian Earth Sciences, v. 39(6), pp. 483-515. doi: 10.1016/j.jseaes.2010.04.026.

Mohanty, M. and Guha, D. B. (1995) Lithotectonic stratigraphy of the dismembered greenstone sequence of the Mangalwar Complex around Lawa-Sardargarh and Parasali areas, Rajsamand District, Rajasthan. Memoir Geological Society of India, v. 31, pp. 141-162.

Mondal, M. E. A. and Raza, A. (2013) Geochemistry of sanukitoid series granitoids from the Neoarchaean Berach granitoid batholiths, Aravalli craton, northwestern Indian shield. Current Science, v. 105(1), pp. 102-108.

Naha, K. and Halyburton, R. V. (1974) Early Precambrian stratigraphy of central and southern Rajasthan, India. Precambrian Research, v. 1(1), pp. 55-73. doi: 10.1016/0301-9268(74)90018-7.

Naha, K. and Roy, A. B. (1983) The problem of the Precambrian basement in Rajasthan, western India. Precambrian Research, v. 19(3), pp. 217-223. doi: 10.1016/0301-9268(83)90014-1.

Naqvi, S. M. and Rogers, J. J. W. (1987) Precambrian Geology of India. New York: Oxford Univ. Press [u.a.] (Oxford monographs on geology and geophysics, 6).

Rahaman, M. S. and Mondal, M. E. A. (2015) Evolution of continental crust of the Aravalli craton, NW India, during the Neoarchaean-Palaeoproterozoic: evidence from geochemistry of granitoids. International Geology Review, v. 57(11-12), pp. 1510-1525. doi: 10.1080/00206814.2014.950607.

Ramakrishnan, M. and Vaidyanadhan, R. (2008) Geology of India. Bangalore: Geological Society of India. 
Open access e-Journal

Earth Science India, eISSN: $0974-8350$

Vol. 9 (IV), October, 2016, pp. 167 - 175

http://www.earthscienceindia.info/

Roy, A. B. (1988) Stratigraphic and tectonic framework of the Aravalli Mountain Range. In: A. B. Roy, (ed.) Precambrian of the Aravalli Mountain, Rajasthan, India. Memoir Geological Society of India, pp. 3-31.

Roy, A. B. and Jakhar, S. R. (2002) Geology of Rajasthan (Northwest India): Precambrian to recent. Jodhpur, India: Scientific Publishers.

Roy, A. B. and Kroner, A. (1996) Single zircon evaporation ages constraining the growth of the Archaean Aravalli craton, northwestern Indian shield. Geological Magazine, v. 133(3), pp. 333-342. doi: $10.1017 / \mathrm{S} 0016756800009067$.

Roy, A. B., Kroner, A. and Laul, V. (2001) Detrital zircons constraining basement age in a late Archaean greenstone belt of south-eastern Rajasthan, India. Current Science, v. 81(4), pp. 407-410.

Sarkar, G., Barman, T. R. and Corfu, F. (1989) Timing of continental arc-type magmatism in northwest India: evidence from $\mathrm{U}-\mathrm{Pb}$ zircon geochronology. Journal of Geology, v. 97(5), pp. 607-612.

Sharma, R. S. (2010) Cratons of the Indian Shield. pp. 41-115. In: R. S. Sharma (ed.) Cratons and Fold Belts of India. Berlin, Heidelberg: Springer-Verlag Berlin Heidelberg, doi:10.1007/978-3-642-01459-8_2. Available at: http://link.springer.com/10.1007/978-3-642-01459-8_2 (Accessed: 13 May 2015).

Upadhyaya, R., Sharma Jr, B. L., Sharma Sr, B. L. and Roy, A. B. (1992) Remnants of greenstone sequence from the Archaean rocks of Rajasthan. Current Science, v. 63(2), pp. 87-92.

Wiedenbeck, M. and Goswami, J. N. (1994) High precision ${ }^{207} \mathrm{~Pb} /{ }^{206} \mathrm{~Pb}$ zircon geochronology using a small ion microprobe. Geochimica et Cosmochimica Acta, v. 58(9), pp. 2135-2141. doi: 10.1016/00167037(94)90291-7.

Wiedenbeck, M., Goswami, J. N. and Roy, A. B. (1996) Stabilization of the Aravalli Craton of northwestern India at $2.5 \mathrm{Ga}$ : An ion microprobe zircon study. Chemical Geology, v. 129(3-4), pp. 325-340. doi: $10.1016 / 0009-2541(95) 00182-4$.

(Received: 12.05. 2016; Accepted: 29.10.2016) 